\title{
Perioperative routines and surgical techniques for saphenous vein harvesting in CABG surgery: a national cross-sectional study in Sweden
}

Hanna Larsson ${ }^{1,2^{*}}$ (D), Maria Hälleberg-Nyman ${ }^{2}$, Örjan Friberg ${ }^{1}$ and Karin Falk-Brynhildsen ${ }^{2}$

\begin{abstract}
Background: The saphenous vein is the most commonly used conduit for coronary artery bypass grafting (CABG). Wound healing complications related to saphenous vein harvesting are common, with reported surgical site infection rates ranging from 2 to 20\%. Patients' risk factors, perioperative hygiene routines, and surgical technique play important roles in wound complications. Here we describe the perioperative routines and surgical methods of Swedish operating theatre (OT) nurses and cardiac surgeons.

Methods: A national cross-sectional survey with descriptive design was conducted to evaluate perioperative hygiene routines and surgical methods associated with saphenous vein harvesting in CABG. A web-based questionnaire was sent to OT nurses and cardiac surgeons at all eight hospitals performing CABG surgery in Sweden.

Results: Responses were received from all hospitals. The total response rate was 62/119 (52\%) among OT nurses and 56/111 (50\%) among surgeons.

Chlorhexidine $5 \mathrm{mg} / \mathrm{mL}$ in 70\% ethanol was used at all eight hospitals. The OT nurses almost always (96.8\%) performed the preoperative skin disinfection, usually for three to 5 minutes. Chlorhexidine was also commonly used before dressing the wound.

Conventional technique was used by $78.6 \%$ of the surgeons, "no-touch" by $30.4 \%$, and both techniques by $9 \%$. None of the surgeons used endoscopic vein harvesting. Type of suture and technique used for closing the wound differed markedly between the centres.

Conclusions: In this article we present insights into the hygiene routines and surgical methods currently used by OT nurses and cardiac surgeons in Sweden. The results indicate both similarities and differences between the centres. Local traditions might be the most important factors in determining which procedures are employed in the OT. There is a lack of evidence-based hygiene routines and surgical methods.
\end{abstract}

Keywords: Perioperative hygiene routines, Surgical methods, Vein harvesting

\footnotetext{
* Correspondence: hanna.larsson@regionorebrolan.se

${ }^{1}$ Department of Cardiothoracic and Vascular Surgery, Faculty of Medicine and Health, Örebro University, Örebro, Sweden

${ }^{2}$ Faculty of Health and Medicine, School of Health Sciences, Örebro

University, SE-701 82 Örebro, Sweden
}

(c) The Author(s). 2020 Open Access This article is distributed under the terms of the Creative Commons Attribution 4.0 International License (http://creativecommons.org/licenses/by/4.0/), which permits unrestricted use, distribution, and reproduction in any medium, provided you give appropriate credit to the original author(s) and the source, provide a link to the Creative Commons license, and indicate if changes were made. The Creative Commons Public Domain Dedication waiver (http://creativecommons.org/publicdomain/zero/1.0/) applies to the data made available in this article, unless otherwise stated. 


\section{Background}

The saphenous vein (SV) is the most commonly used conduit for coronary artery bypass grafting (CABG) [1, 2]. Wound healing complications related to saphenous vein harvesting $(\mathrm{SVH})$ are common, with reported surgical site infection (SSI) rates ranging from 2 to 20\% [3, 4]. Such complications are both a major cause of patient morbidity and an economic burden for the health care system [5]. Patient-dependent risk factors for SSI include diabetes, obesity, advanced age, female gender, and peripheral vascular disease [1, 3]. Several perioperative hygiene routines are aimed at maintaining an aseptic environment and avoiding endogenous or exogenous bacterial contamination: patient skin preparation and draping, routines for handling the surgical equipment, and postoperative dressing $[6,7]$.

The surgical techniques used for harvesting the SV and closing the wound also play an important role in wound complications $[8,9]$. The open harvest technique, which uses a longitudinal skin incision over the vein, might facilitate the occurrence of wound complications. As an alternative to the open conventional technique (CT), the "no-touch" technique (NT), where the vein is harvested along with the perivascular adipose tissue was introduced at our department and published for the first time in 1996 [10]. When closing the wound, the number of subcutaneous suture layers as well as the choice of the suture material might influence the incidence of complications [11-13]. An endoscopic vein harvesting $(\mathrm{EVH})$ technique can also be used in order to reduce the incidence of wound complications [8].

The perioperative hygiene routines and varieties in surgical methods for SVH are unfortunately often poorly evaluated scientifically. We therefore hypothesised that these routines might be based more on local traditions than on scientific evidence, and that surgical methods might differ substantially between different centres. To our knowledge, no previous studies have investigated current routines and surgical methods regarding $\mathrm{SVH}$ for CABG.

The aim of this nationwide study was to determine current practice in terms of perioperative hygiene routines and surgical methods used by Swedish OT nurses and cardiac surgeons regarding saphenous vein harvesting for CABG.

\section{Methods}

\section{Study design and setting}

The study had a descriptive design. A national webbased cross-sectional survey regarding perioperative routines and surgical methods associated with SVH for CABG was conducted in Sweden during February and March 2018.

\section{Questionnaires}

Two study-specific self-report web questionnaires were constructed, one for OT nurses and one for surgeons, with questions concerning perioperative hygiene routines as well as surgical methods. (In Sweden, the OT nurse prepares the patient for the surgical procedure.)

The survey was sent to all OT nurses and surgeons, since it was not possible to select only those who performed CABG. The study-specific questionnaires were based on both existing research $[1,2,8,9,11,14-18]$ and the authors' own clinical experience as OT nurses, a nurse, and a cardiothoracic surgeon.

The OT nurses were asked 32 open-ended questions regarding hygiene routines, dressing, and compression of the leg wound. The surgeons were asked 17 questions focusing on surgical technique regarding harvesting the SV, closing the wound, and type of suture. Questions regarding postoperative complications will be presented elsewhere.

Before the questionnaire was distributed, a pilot test was carried out among one OT nurse with context knowledge and one anaesthetic nurse with methodological knowledge at our institution, in order to test the content and its understanding. No corrections were needed after feedback from these two nurses. The OT nurse who pilot-tested the questionnaire was included in the study.

Reminders were sent after two and 4 weeks to those who had not yet answered the web questionnaire.

\section{Participants}

The survey was sent to all surgeons and OT nurses at all eight hospitals where CABG surgery is performed in Sweden: Karlskrona Hospital, Karolinska University Hospital, Linköping University Hospital, Lund University Hospital, Sahlgrenska University Hospital, Umeå University Hospital, Uppsala University Hospital, and Örebro University Hospital. The surgeons were identified from the membership list of the Swedish Association for Cardiothoracic Surgery, including both consultant surgeons and residents. The OT nurses were identified by the head of the section at each hospital.

\section{Ethical considerations}

The Regional Ethical Review Board of Uppsala, Sweden, advised that no formal ethical approval was required (reference number: 2017/519). The results from the questionnaire were confidential, and no associations were made between the results and any specific surgeon or OT nurse.

\section{Statistical analysis}

Data were analysed using version 22 of the SPSS software package (SPSS 22 IBM, SPSS Inc., Chicago, USA). 


\section{Results}

Responses were received from all hospitals. Among the 119 OT nurses and 111 surgeons who were identified, the total response rate was $62 / 119$ (52\%) from the OT nurses and 56/111 (50\%) from the surgeons.

\section{Perioperative routines}

The OT nurses almost always (96.8\%) performed the preoperative skin disinfection. Chlorhexidine $5 \mathrm{mg} / \mathrm{mL}$ in $70 \%$ ethanol was used in all cases. The skin disinfection was most commonly performed for three to $5 \mathrm{mi}$ nutes. Incision film was seldom used on the legs. The instruments for harvesting the saphenous vein were separated from the ones used in the sternal wound by $93.5 \%$ of the OT nurses, and $75.8 \%$ used a separate table for the leg wound surgeon (Table 1).

Almost all OT nurses (98.4\%) reported that the assistant surgeon changed gloves after SVH and before assisting in the sternal wound (Table 2). Cleaning the leg wound with chlorhexidine $5 \mathrm{mg} / \mathrm{mL}$ in $70 \%$ ethanol was common before dressing, and the majority of the nurses reported that they paid special attention to removing clots and blood from deep within the leg wound. Semipermeable dressings were used by $51.6 \%$ and nonpermeable dressings by $45.2 \%$ of the OT nurses. Most nurses applied an elastic bandage after the wound was dressed.

\section{Surgical methods}

Data on the surgeons' vein harvest techniques are shown in Table 3. The majority of the surgeons used CT for SVH, while $30.4 \%$ used NT. Some of the respondents used both techniques. Notably, none in this study used EVH.

The use of no or only one subcutaneous suture layer was most common, but $16.1 \%$ used two layers. There was a marked variation in the use of braided or monofilament subcutaneous sutures as well as of triclosancontaining sutures, with equal proportions of surgeons reporting that they never or always used them. All respondents in the study sutured the wound intracutaneously; none used skin staplers.

\section{Discussion}

This study is the first survey describing perioperative hygiene routines and surgical methods regarding $\mathrm{SVH}$ in Sweden. The main finding was that although perioperative hygiene routines were similar between the centres and the interventions recommended by the national guidelines were implemented in daily work, aspects such as the techniques for harvesting the vein and closing the wound differed markedly between the surgeons and centres.

There are differences internationally regarding preoperative preparation of the surgical patient. Depending on country, the patient may be prepared in the OT by the surgeon or by nurses with differing educational levels and training. In Sweden, the OT nurse has an independent role and takes responsibility for OT aseptic techniques, skin preparation and draping of the patient, and generally maintaining good care for the surgical patient, such as preventing hypothermia and decubitus $[7,19]$.

Chlorhexidine $5 \mathrm{mg} / \mathrm{mL}$ in $70 \%$ ethanol was used in all centres, and the skin disinfection was most commonly performed for three to 5 minutes according to national guidelines [20]. Almost all of the OT nurses had a separate table and/or separate instruments for the vein harvesting, a standard routine which probably stems from a general belief that bacteria can spread from the leg wound to the sternotomy. However, in contradiction of this belief, we showed in a previous study that there is almost no intraoperative bacterial growth on the skin or in the subcutaneous tissue at the harvest site on the leg [18]. In contrast, there is bacterial growth subcutaneously in the sternotomy during surgery in most patients [21]. Thus, in our opinion, the generally accepted routine in which the assistant surgeon changes gloves after vein harvesting lacks evidence and is not justified. On the other hand, studies have shown that the micro perforation rate of gloves increases over time, and bacteria could possibly pass through the perforation [22-24] and contaminate the wound. There are no Swedish guidelines for when surgical gloves should be changed, but international guidelines from the Association of Perioperative Registered Nurses [25] recommend changing the outer glove every $90 \mathrm{~min}$ whether the gloves are macroscopically damaged or not. It could be relevant to apply these guidelines also in Sweden.

The harvest technique has a contributory role in the development of leg wound SSI. The open harvest approach increases the risk for SSI compared with the EVH technique $[8,9,15]$. However, some studies report that the EVH technique might impair graft patency [8, 26]. This might be the main reason why, in this study, the open vein harvesting technique was used by $100 \%$ of respondents. The NT has gradually increased in popularity [27], possibly because graft patency with this technique have been demonstrated to be superior to those with CT $[17,28]$. Nevertheless, CT was used by $78.6 \%$ of the participants in the present study. It remains to be seen whether the choice of CT or NT for open vein harvesting technique significantly influences the rate of leg wound SSI, but results from at least one ongoing large multicentre randomised controlled trial comparing the two techniques (NCT03501303) should provide more information.

Our participants differed in terms of the subcutaneous suture layer and types of sutures used to close the leg wound. One study found that the subcutaneous suture did not reduce the postoperative infection rate [12], 
Table 1 Operating theatre nurses' preoperative routines regarding saphenous vein harvesting

\begin{tabular}{lc}
\hline Variable & $\begin{array}{c}\text { OT nurses } \\
(N=62)\end{array}$ \\
\hline Place of preparing equipment and surgical instruments, $\mathrm{n}(\%)$ & $11(17.7)$ \\
In the preparation room & $51(82.3)$ \\
In the OT & \\
The sterile table is covered preoperatively, $\mathrm{n}(\%)$ & $59(95.2)$ \\
Yes & $3(4.8)$ \\
No
\end{tabular}

Time of preparing equipment and surgical instruments, $\mathrm{n}(\%)$

Before the patient arrives in the OT

$56(90.3)$

When the patient is being prepared in the OT

$6(9.7)$

Separate table for instruments used in the vein harvesting, $\mathrm{n}(\%)$

Yes

$47(75.8)$

No

$15(24.2)$

Separate instruments used in the vein harvesting, $\mathrm{n}(\%)$

Yes

58 (93.5)

No

$4(6.5)$

Skin disinfection, $\mathrm{n}(\%)$

OT nurse

$60(96.8)$

Surgeon

$1(1.6)$

Assistant

$1(1.6)$

Skin disinfection solution, $\mathrm{n}(\%)$

Chlorhexidine $5 \mathrm{mg} / \mathrm{ml}$ in $70 \%$ ethanol

Ethanol 70\%

$0(0)$

lodine

$0(0)$

$0(0)$

Chloraprep 2\%

$18(29.0)$

$36(58.1)$

$8(12.9)$

5-10 min

Tinted skin disinfection solution, $\mathrm{n}(\%)^{\mathrm{a}}$

Yes

No

$39(62.9)$

21 (33.9)

Skin disinfection of both legs, $\mathrm{n}(\%)$

Yes

44 (71.0)

No

18 (29.0)

Leg lift for skin disinfection, $\mathrm{n}(\%)$

Manually by staff

$53(85.5)$

Leg lift device

Incision film on the leg/legs, n (\%)

Always/almost always

Always/almost always on any damaged skin on the leg

Sometimes

1 (1.6)

$0(0)$

Never/almost never

$61(98.4)$
Table 1 Operating theatre nurses' preoperative routines regarding saphenous vein harvesting (Continued)

\begin{tabular}{ll}
\hline Variable & $\begin{array}{l}\text { OT nurses } \\
(N=62)\end{array}$ \\
\hline $\begin{array}{ll}\text { Incision film with iodine, n (\%) } \\
\text { Yes }\end{array}$ & $9(14.5)$ \\
No & $12(19.4)$ \\
Never use incision film & $41(66.1)$ \\
Integuseal on the leg/legs, n (\%) ${ }^{\mathrm{a}}$ & \\
Always/almost always & $0(0)$ \\
Sometimes & $1(1.6)$ \\
Never/almost never & $58(93.5)$ \\
Non-operated leg is covered, $\mathrm{n}(\%)^{\mathrm{a}}$ & \\
Always/almost always & $42(67.7)$ \\
Sometimes & $12(19.4)$ \\
Never/almost never & $6(9.7)$
\end{tabular}

Vein harvesting begins before the patient is totally draped for the heart surgery, $\mathrm{n}(\%)^{\mathrm{a}}$

\begin{tabular}{ll} 
Always/almost always & $10(16.1)$ \\
Sometimes & $10(16.1)$ \\
Never/almost never & $41(66.1)$ \\
\hline
\end{tabular}

${ }^{a}$ Missing answer from OT nurse/nurses

while another showed that wound gaps were associated with SSI in the leg [11]. The latter study [11] also showed that the choice of suture and suturing technique is important to prevent SSI in the leg. A lower rate of SSI has been found in cases where the assistant surgeon was experienced [12]. Approximately half of the surgeons in the present study used sutures coated with triclosan. Prospective randomised studies have yielded differing results $[13,29]$. In one study of 328 CABG patients, triclosan-coated sutures did not reduce SSI in the leg wound [29]. However, in a later randomised controlled trial of 374 patients, the SSI rate was significantly reduced with triclosan sutures [13].

The high incidence of SSI in prospective studies is a pertinent and troublesome issue, and many factors affect the results. Evidence is lacking, and there are a number of routines and methods which are not based on evidence but have not been de-implemented. One routine lacking evidence is the routine of preparing a separate table and/or separate instruments for the vein harvesting, mentioned above. De-implementation is a process for identifying and removing practices based on tradition and habits which lack adequate scientific support [30]. In the pursuit of evidence-based health care, deimplementation of old routines is just as important as the implementation of new evidence. The difficulties and success factors for introducing evidence-based practice in clinical work have been described in implementation research [31]. It is of the greatest importance to discuss 
Table 2 Operating theatre nurses' intraoperative and postoperative routines regarding saphenous vein harvesting

\begin{tabular}{ll}
\hline Variable & OT nurses $(N=62)$ \\
\hline Gloves changed after vein harvesting, $\mathrm{n}(\%)$ & \\
Always/almost always & $61(98.4)$ \\
Sometimes & $1(1.6)$ \\
Never/almost never & $0(0)$
\end{tabular}

Elastic bandage used intraoperatively, $\mathrm{n}(\%)^{\mathrm{a}}$

$\begin{array}{lc}\text { Always/almost always } & 59(95.2) \\ \text { Sometimes } & 1(1.6) \\ \text { Never/almost never } & 0(0) \\ \text { Position changes used to avoid pressure damage, } \mathrm{n}(\%)^{\mathrm{a}} \\ \text { Always/almost always } & 2(3.2) \\ \text { Sometimes } & 16(25.8) \\ \text { Never/almost never } & 43(69.4) \\ \text { Bleeding control of the leg wound during } \mathrm{ECC}^{\mathrm{b}}, \mathrm{n}(\%) \\ \text { Yes } & 19(30.6) \\ \text { No } & 43(69.4)\end{array}$

Suturing the leg/legs, n (\%)

Attending in cardiothoracic surgery $\quad 6(9.7)$

Resident in cardiothoracic surgery $13(21.0)$

Intern

$29(46.8)$

OR nurse

$4(6.5)$

Other

$10(16.0)$

Drain to the leg, $\mathrm{n}(\%)$

Always/almost always

$0(0)$

Sometimes

$11(17.7)$

Never/almost never

$51(82.3)$

Clots and blood removed before dressing, $\mathrm{n}(\%)$

$\begin{array}{ll}\text { Always/almost always } & 59(95.2) \\ \text { Sometimes } & 3(4.8) \\ \text { Never/almost never } & 0(0) \\ \text { Cleaning solution before dressing, } \mathrm{n}(\%) & \\ \text { Sodium chloride } & 2(3,2) \\ \text { Chlorhexidine } 5 \mathrm{mg} / \mathrm{ml} \text { in } 70 \% \text { ethanol } & 43(69.4) \\ \text { Other chlorhexidine solutions } & 17(27.4)\end{array}$

Semipermeable dressing on the leg/legs, $\mathrm{n}(\%)^{\mathrm{a}}$

Always/almost always

$32(51.6)$

Sometimes

$0(0)$

Never/almost never

$26(41.9)$

Nonpermeable dressing on the leg/legs, $\mathrm{n}(\%)^{\mathrm{a}}$

Always/almost always

$28(45.2)$

Sometimes

$3(4.8)$

$28(45.2)$

Never/almost never

Dressing application on the leg/legs, n (\%)

Attending in cardiothoracic surgery
Table 2 Operating theatre nurses' intraoperative and postoperative routines regarding saphenous vein harvesting (Continued)

\begin{tabular}{ll}
\hline Variable & OT nurses $(N=62)$ \\
\hline Resident in cardiothoracic surgery & $3(4.8)$ \\
Intern & $7(11.3)$ \\
OR nurse & $50(80.6)$ \\
Other & $1(1.6)$
\end{tabular}

Elastic bandage used after the leg wound is dressed, $\mathrm{n}(\%)^{\mathrm{a}}$

$\begin{array}{ll}\text { Always/almost always } & 56(90.3) \\ \text { Sometimes } & 3(4.8) \\ \text { Never/almost never } & 2(3.2)\end{array}$

Compression stocking used after the leg wound is dressed, $n(\%)^{a}$

$\begin{array}{ll}\text { Always/almost always } & 11(17.7) \\ \text { Sometimes } & 0(0) \\ \text { Never/almost never } & 50(80.6) \\ \text { Leg compression, } \mathrm{n}(\%)^{\mathrm{a}} & \\ \text { Lower limb } & 20(32.3) \\ \text { Whole leg } & 41(66.1) \\ \text { No compression } & 0(0) \\ { }^{\mathrm{a} M i s s i n g} \text { answer from OT nurse/nurses } & \end{array}$

and prepare implementation strategies for clinical practice [32].

This national cross-sectional survey was performed in order to identify unjustifiable differences or peculiarities in current practice which might signal a lack of scientific evidence. Our findings could provide a basis for further studies aimed at reducing the incidence of complications after SVH.

\section{Limitation}

One limitation of the study was the self-designed questionnaires, which were used since we found no relevant existing survey material. This carried a risk that essential questions might be missed. To increase the content validity, the questionnaires were tested within a small pilot group before they were distributed to the full group. The response rates for the two questionnaires were 52\% for the OT nurses and $50 \%$ for the surgeons, which may have led to response bias. We could also have sent a postal survey instead of a web-based questionnaire to allow for answering in different ways [33]. We believe that the response rate gives the study moderate external validity. A strength of the study was that there were respondents from all centres in Sweden. No comparisons between centres or respondents were performed.

\section{Conclusion}

In this study we present an insight into the hygiene routines and surgical methods currently used by OT nurses 
Table 3 Cardiac surgeons' routines regarding saphenous vein harvesting

\begin{tabular}{lc}
\hline Variable & Cardioth \\
\hline Own frequency of SVH, n (\%) & \\
$>$ 20 times/year & $32(57.1)$ \\
$11-20$ times/year & $12(21.4)$ \\
$6-10$ times/year & $5(8.9)$ \\
1-5 times/year & $5(8.9)$ \\
Never & $2(3.6)$ \\
Vein harvester, n (\%) & \\
Attending in cardiothoracic surgery & $17(30.4)$ \\
Resident in cardiothoracic surgery & $16(28.6)$ \\
Operating theatre nurse & $5(8.9)$ \\
Intern & $14(25.0)$ \\
Operations assistant & $1(1.8)$ \\
Vein harvester & $2(3.6)$ \\
Common clinical technique for SVH, n (\%) \\
Yes & $12(21.4)$ \\
Partly & $35(62.5)$ \\
No & $7(12.5)$
\end{tabular}

Type of vein graft, $\mathrm{n}(\%)^{\mathrm{a}}$

$\begin{array}{ll}\text { Conventional } & 44(78.6) \\ \text { "No-touch" } & 17(30.4) \\ \text { Endoscopic } & 0(0)\end{array}$

Ligation of side branches, $\mathrm{n}(\%)^{\mathrm{a}}$

Clips

Absorbable ligature

Non-absorbable ligature

$27(48.2)$

Other

Diathermy/coagulation, $\mathrm{n}(\%)$

$\begin{array}{ll}\text { Monopolar diathermy } & 40(71.4) \\ \text { Bipolar diathermy } & 10(17.9) \\ \text { Ultrasound "harmonic scalpel" } & 1(1.8) \\ \text { Never use diathermy } & 3(5.4) \\ \text { Suturing the leg/legs, n (\%) } & \\ \text { Attending in cardiothoracic surgery } & 13(23.2) \\ \text { Resident in cardiothoracic surgery } & 11(19.6) \\ \text { Operating room nurse } & 4(7.1) \\ \text { Intern } & 23(41.1) \\ \text { Operations assistant } & 1(1.8) \\ \text { Vein harvester } & 2(3.6) \\ \text { Skin suture, n (\%) } & \\ \text { Intracutaneous suture } & 54(96.4) \\ \text { Skin staples } & 0(0)\end{array}$

Suture layers in subcutis, n (\%)

One layer
Table 3 Cardiac surgeons' routines regarding saphenous vein harvesting (Continued)

\begin{tabular}{ll}
\hline Variable & Cardiothoracic surgeon (N=56) \\
\hline Two layer & $9(16.1)$ \\
No subcutaneous layer & $22(39.3)$ \\
Subcutaneous suture, $\mathrm{n}(\%)$ & \\
Braided & $23(41.1)$ \\
Monofilament & $24(42.9)$ \\
No subcutaneous suture & $9(16.1)$ \\
Intracutaneous suture, $\mathrm{n}(\%)$ & \\
Braided & $4(7.1)$ \\
Monofilament & $50(89.3)$ \\
Suture with triclosan (Vicryl+), n (\%) & \\
Always & $23(41.1)$ \\
Sometimes & $9(16.1)$ \\
Never & $22(39.3)$ \\
\hline an is more than 56 because it was possible to give more than one answer
\end{tabular}

and cardiac surgeons in Sweden. The results indicate both similarities and differences between the centres. There is a lack of evidence regarding common routines and methods. Local tradition might be one of the most important factor determining which procedures are employed in the OT.

\section{Abbreviations}

CABG: Coronary artery bypass grafting; $\mathrm{CT}$ : Conventional technique; EVH: Endoscopic vein harvesting; NT: "No-touch" technique; OT: Operating theatre; SSI: Surgical site infection; SV: Saphenous vein; SVH: Saphenous vein harvesting

\section{Acknowledgements}

The authors wish to thank Birgitta Eriksson, librarian at Örebro University.

\section{Authors' contributions}

All authors contributed to the study design, to the analysis of the data, to writing the manuscript and in approving the final version. HL collected data and was the major contributor in writing the manuscript. All authors read and approved the final manuscript.

\section{Funding}

This study was supported by Örebro University Hospital research committee and Örebro University. Open access funding provided by Örebro University.

\section{Availability of data and materials}

The datasets used and/or analysed during the current study are available from the corresponding author on reasonable request.

\section{Ethics approval and consent to participate}

The Regional Ethical Review Board of Uppsala, Sweden advised that no formal ethical approval was required.

\section{Consent for publication}

Not applicable.

Competing interests

The authors declare that they have no competing interests. 
Received: 2 October 2019 Accepted: 3 January 2020

\section{- 20.}

\section{References}

1. Sharma M, Fakih MG, Berriel-Cass D, Meisner S, Saravolatz L, Khatib R. Harvest surgical site infection following coronary artery bypass grafting: risk factors, microbiology, and outcomes. Am J Infect Control. 2009;37(8):653-7.

2. Athanasiou T, Aziz O, Skapinakis P, Perunovic B, Hart J, Crossman M-C, et al. Leg wound infection after coronary artery bypass grafting: a meta-analysis comparing minimally invasive versus conventional vein harvesting. Ann Thorac Surg. 2003;76(6):2141-6.

3. Swenne CL, Lindholm C, Borowiec J, Carlsson M. Surgical-site infections within 60 days of coronary artery by-pass graft surgery. J Hosp Infect. 2004; 57(1):14-24.

4. Garland R, Frizelle FA, Dobbs BR, Singh H. A retrospective audit of long-term lower limb complications following leg vein harvesting for coronary artery bypass grafting. Eur J Cardiothorac Surg. 2003;23(6):950-5.

5. Allegranzi B, Bischoff P, de Jonge S, Kubilay NZ, Zayed B, Gomes SM, et al. New WHO recommendations on preoperative measures for surgical site infection prevention: an evidence-based global perspective. Lancet Infect Dis. 2016;16(12):e276-87.

6. Riksföreningen för Operationssjukvård \& Svensk Sjuksköterskeförening. Kompetensbeskrivning för legitimerad sjuksköterska med specialistsjuksköterskeexamen inriktning mot operationsjjukvård. 2011. http:// www.ffop.se/media/1254/kompbeskrivning.pdf. Accessed 22 May 2019.

7. Kelvered M, Ohlen J, Gustafsson BA. Operating theatre nurses' experience of patient-related, intraoperative nursing care. Scand J Caring Sci. 2012;26(3): 449-57.

8. Mannion JD, Marelli D, Brandt T, Stallings M, Cirks J, Dreifaldt M, et al. "Notouch" versus "endo" vein harvest: early patency on symptom-directed catheterization and harvest site complications. Innovations (Phila). 2014;9(4): 306-11.

9. Krishnamoorthy B, Critchley WR, Glover AT, Nair J, Jones MT, Waterworth $\mathrm{PD}$, et al. A randomized study comparing three groups of vein harvesting methods for coronary artery bypass grafting: endoscopic harvest versus standard bridging and open techniques. Interact Cardiovasc Thorac Surg. 2012;15(2):224-8.

10. Souza D. A new no-touch preparation technique. Technical notes. Scand J Thorac Cardiovasc Surg. 1996;30(1):41-4.

11. Swenne CL, Borowiec J, Carlsson M, Lindholm C. Prediction of and risk factors for surgical wound infection in the saphenous vein harvesting leg in patients undergoing coronary artery bypass. Thorac Cardiovasc Surg. 2006; 54(5):300-6.

12. Stenvik M, Tjomsland O, Lien S, Gunnes S, Kirkeby-Garstad I, Astudillo R. Effect of subcutaneous suture line and surgical technique on wound infection after saphenectomy in coronary artery bypass grafting: a prospective randomised study. Scand Cardiovasc J. 2006;40(4):234-7.

13. Thimour-Bergstrom L, Roman-Emanuel C, Schersten H, Friberg O, Gudbjartsson T, Jeppsson A. Triclosan-coated sutures reduce surgical site infection after open vein harvesting in coronary artery bypass grafting patients: a randomized controlled trial. Eur J Cardiothorac Surg. 2013;44(5):931-8.

14. Biancari F, Tiozzo V. Staples versus sutures for closing leg wounds after vein graft harvesting for coronary artery bypass surgery. Cochrane Database Syst Rev. 2010;(5):CD008057. https://doi.org/10.1002/14651858.CD008057.pub2.

15. Luckraz H, Kaur P, Bhabra M, Mishra PK, Nagarajan K, Kumari N, et al. Endoscopic vein harvest in patients at high risk for leg wound complications: a cost-benefit analysis of an initial experience. Am J Infect Control. 2016;44(12):1606-10.

16. East SA, Lorenz RA, Armbrecht ES. A retrospective review of leg wound complications after coronary artery bypass surgery. AORN J. 2013;98(4):401-12.

17. Souza DS, Dashwood MR, Tsui JC, Filbey D, Bodin L, Johansson B, et al. Improved patency in vein grafts harvested with surrounding tissue: results of a randomized study using three harvesting techniques. Ann Thorac Surg. 2002;73(4):1189-95.

18. Falk-Brynhildsen $\mathrm{K}$, Soderquist B, Friberg $\mathrm{O}$, Nilsson U. Bacterial growth and wound infection following saphenous vein harvesting in cardiac surgery: a randomized controlled trial of the impact of microbial skin sealant. Eur J Clin Microbiol Infect Dis. 2014;33(11):1981-7.

19. Wistrand C, Falk-Brynhildsen K, Nilsson U. National survey of operating room nurses' aseptic techniques and interventions for patient preparation to reduce surgical site infections. Surg Infect. 2018;19(4):438-45.
20. Swedish Association of Local Authorities and Regions. The Handbook for Healthcare. 2002. https://www.vardhandboken.se/om/om-vardhandboken/ in-english/. Accessed 27 May 2019.

21. Falk-Brynhildsen K, Soderquist B, Friberg O, Nilsson UG. Bacterial recolonization of the skin and wound contamination during cardiac surgery: a randomized controlled trial of the use of plastic adhesive drape compared with bare skin. J Hosp Infect. 2013;84(2):151-8.

22. Eklund AM, Ojajarvi J, Laitinen K, Valtonen M, Werkkala KA. Glove punctures and postoperative skin flora of hands in cardiac surgery. Ann Thorac Surg. 2002;74(1):149-53.

23. Harnoss JC, Partecke LI, Heidecke CD, Hubner NO, Kramer A, Assadian O. Concentration of bacteria passing through puncture holes in surgical gloves. Am J Infect Control. 2010;38(2):154-8.

24. Partecke LI, Goerdt AM, Langner I, Jaeger B, Assadian O, Heidecke CD, et al. Incidence of microperforation for surgical gloves depends on duration of wear. Infect Control Hosp Epidemiol. 2009;30(5):409-14.

25. Association of Perioperative Registered Nurses. Guidelines for hand hygiene. In: Guidelines for perioperative practice; 2016. Available from: https://www. aorn.org/. Accessed 15 May 2019.

26. Harky A, Balmforth D, Shipolini A, Uppal R. Is endoscopic long saphenous vein harvesting equivalent to open harvesting technique in terms of graft patency? Interact Cardiovasc Thorac Surg. 2017;25(2):323-6.

27. Deb S, Singh SK, de Souza D, Chu MWA, Whitlock R, Meyer SR, et al. SUPERIOR SVG: no touch saphenous harvesting to improve patency following coronary bypass grafting (a multi-Centre randomized control trial, NCT01047449). J Cardiothorac Surg. 2019;14(1):85.

28. Samano N, Geijer H, Liden M, Fremes S, Bodin L, Souza D. The no-touch saphenous vein for coronary artery bypass grafting maintains a patency, after 16 years, comparable to the left internal thoracic artery: a randomized trial. J Thorac Cardiovasc Surg. 2015;150(4):880-8.

29. Seim BE, Tonnessen T, Woldbaek PR. Triclosan-coated sutures do not reduce leg wound infections after coronary artery bypass grafting. Interact Cardiovasc Thorac Surg. 2012;15(3):411-5.

30. Upvall MJ, Bourgault AM. De-implementation: a concept analysis. Nurs Forum. 2018. https://doi.org/10.1111/nuf.12256.

31. Harvey G, Kitson A. PARIHS revisited: from heuristic to integrated framework for the successful implementation of knowledge into practice. Implement Sci. 2016;11:33.

32. Proctor EK, Powell BJ, McMillen JC. Implementation strategies: recommendations for specifying and reporting. Implement Sci. 2013;8:139.

33. Phillips AW, Reddy S, Durning SJ. Improving response rates and evaluating nonresponse bias in surveys: AMEE guide no. 102. Med Teach. 2016;38(3): $217-28$

\section{Publisher's Note}

Springer Nature remains neutral with regard to jurisdictional claims in published maps and institutional affiliations.

Ready to submit your research? Choose BMC and benefit from:

- fast, convenient online submission

- thorough peer review by experienced researchers in your field

- rapid publication on acceptance

- support for research data, including large and complex data types

- gold Open Access which fosters wider collaboration and increased citations

- maximum visibility for your research: over $100 \mathrm{M}$ website views per year

At BMC, research is always in progress.

Learn more biomedcentral.com/submissions 